Prepared in cooperation with the Connecticut Department of Public Health

\title{
Arsenic and Uranium Occurrence in Private Wells in Connecticut, 2013-18-A Spatially Weighted and Bedrock Geology Assessment
}

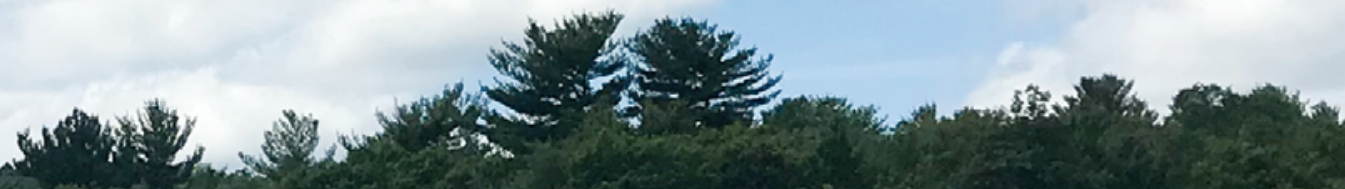

Open-File Report $2020-1111$

Version 1: 1 , November 2020

US Department of the hiterior US Geological Sulver 
Cover. Farmington River in Collinsville, Connecticut. Photo by Tiziana Shea. 


\section{Arsenic and Uranium Occurrence in Private Wells in Connecticut, 2013-18- A Spatially Weighted and Bedrock Geology Assessment}

By Eliza L. Gross and Craig J. Brown

Prepared in cooperation with the Connecticut Department of Public Health

Open-File Report 2020-1111

Version 1.1, November 2020 


\title{
U.S. Department of the Interior DAVID BERNHARDT, Secretary
}

\section{U.S. Geological Survey James F. Reilly II, Director}

\author{
U.S. Geological Survey, Reston, Virginia: 2020 \\ First release: 2020 \\ Revised: November 2020 (ver. 1.1)
}

For more information on the USGS —-the Federal source for science about the Earth, its natural and living resources, natural hazards, and the environment-visit https://www.usgs.gov or call 1-888-ASK-USGS.

For an overview of USGS information products, including maps, imagery, and publications,

visit https://store.usgs.gov.

Any use of trade, firm, or product names is for descriptive purposes only and does not imply endorsement by the U.S. Government.

Although this information product, for the most part, is in the public domain, it also may contain copyrighted materials as noted in the text. Permission to reproduce copyrighted items must be secured from the copyright owner.

Suggested citation:

Gross, E.L., and Brown, C.J., 2020, Arsenic and uranium occurrence in private wells in Connecticut, 2013-18 - a spatially weighted and bedrock geology assessment: U.S. Geological Survey Open-File Report 2020-1111 (ver. 1.1, November 2020), 13 p., https://doi.org/10.3133/ofr20201111.

Associated data for this publication:

Gross, E.L, 2020, Data in support of "Arsenic and Uranium Occurrence in Private Wells in Connecticut, 2013-18, a Spatially-Weighted and Bedrock Geology Assessment": U.S. Geological Survey data release, https://doi.org/ 10.5066/P9KOU55K.

ISSN 2331-1258 (online) 


\section{Acknowledgments}

This study was conducted in cooperation with the Connecticut Department of Public Health (DPH) as part of their cooperative agreement with the National Center for Environment Health of the Centers for Disease Control and Prevention of the U.S. Department of Health and Human Services to provide support for public health drinking water programs to reduce drinking water exposures to contaminants. The authors thank Laura Apinis and Sue Isch of the DPH Laboratory for sample analyses and Gary Archambault, Ryan Tetreault, and Tiziana Shea of the DPH for the site location data used in this study. 


\section{Contents}

Acknowledgments ........................................................................................................................

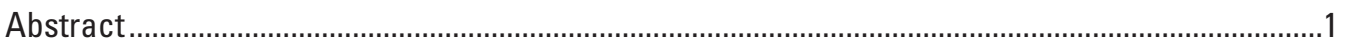

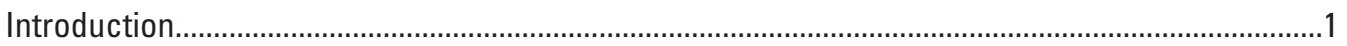

Arsenic and Uranium Concentration Data Sources ................................................................

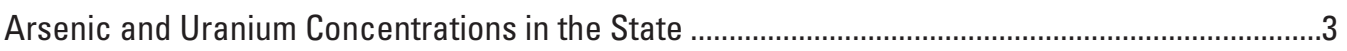

Arsenic and Uranium Spatially Weighted Assessment..................................................................

Arsenic and Uranium Occurrence in Relation to Bedrock Geology .............................................6

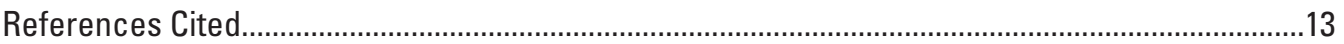

\section{Figures}

1. Concentrations of $A$, arsenic in water samples from 2,433 private wells and $B$, uranium in water samples from 2,191 private wells in Connecticut, 2013-18...

2. Spatially weighted statewide-scale proportion of wells within grid cells for arsenic and uranium

3. Spatial distribution and range of percentages of private wells in Connecticut, grouped by geologic units, in which $A$, arsenic concentrations exceeded the maximum concentration level (MCL) of 10 micrograms per liter $(\mu \mathrm{g} / \mathrm{L})$, and $B$, uranium concentrations exceeded the MCL of $30 \mu \mathrm{g} / \mathrm{L}$

\section{Tables}

1. Inventory of standard reference samples for arsenic and uranium concentrations, 2015-18

2. Arsenic concentrations in water samples from 2,433 private wells and uranium concentrations in water samples from 2,191 private wells in Connecticut, 2013-18........5

3. Spatially weighted statewide-scale proportions for arsenic and uranium during 2013-18 from the Connecticut Department of Public Health database..

4. Arsenic and uranium concentrations that exceed U.S. Environmental Protection Agency's maximum contaminant levels in samples from private wells in Connecticut, by geologic unit and major bedrock category, 2013-18 


\section{Conversion Factors}

U.S. customary units to International System of Units

\begin{tabular}{lccc}
\hline & Multiply & By & To obtain \\
\hline & Length & \\
\hline mile $(\mathrm{mi})$ & 1.609 & kilometer $(\mathrm{km})$ \\
\hline
\end{tabular}

\section{Datum}

Vertical coordinate information is referenced to the North American Vertical Datum of 1988 (NAVD 88).

Horizontal coordinate information is referenced to the North American Datum of 1983 (NAD 83).

Altitude, as used in this report, refers to distance above the vertical datum.

\section{Supplemental Information}

Concentrations of chemical constituents in water are given in micrograms per liter $(\mu \mathrm{g} / \mathrm{L})$.

\section{Abbreviations}

DPH Connecticut Department of Public Health

EPA U.S. Environmental Protection Agency

MCL maximum contaminant level

USGS U.S. Geological Survey 


\title{
Arsenic and Uranium Occurrence in Private Wells in Connecticut, 2013-18-A Spatially Weighted and Bedrock Geology Assessment
}

\author{
By Eliza L. Gross and Craig J. Brown
}

\section{Abstract}

The U.S. Geological Survey, in cooperation with the Connecticut Department of Public Health, conducted a study to determine the presence of arsenic and uranium in private drinking water wells in Connecticut. Samples were collected during 2013-18 from wells completed in 115 geologic units, with 2,433 samples analyzed for arsenic and 2,191 samples analyzed for uranium. The study concluded four major findings.

- In a spatially weighted analysis of groundwater samples collected from more than 2,000 private wells in bedrock aquifers in Connecticut, 3.9 percent of collected samples contained arsenic concentrations greater than the U.S. Environmental Protection Agency's (EPA) maximum contaminant level (MCL) of 10 micrograms per liter $(\mu \mathrm{g} / \mathrm{L})$, and 4.7 percent of collected samples contained uranium concentrations greater than the EPA MCL of $30 \mu \mathrm{g} / \mathrm{L}$.

- Of the 2,433 water samples collected and analyzed from bedrock aquifers in Connecticut, 4.2 percent (102) contained arsenic concentrations at greater than $10 \mu \mathrm{g} / \mathrm{L}$, and of the 2,191 water samples collected and analyzed from bedrock aquifers in Connecticut, 5.4 percent (118) contained uranium concentrations greater than $30 \mu \mathrm{g} / \mathrm{L}$.

- Uranium concentrations greater than or equal to $1 \mu \mathrm{g} / \mathrm{L}$ are relatively ubiquitous across the State of Connecticut, with these concentrations present in 44.9 percent of the State, according to spatially weighted statewidescale proportion analysis.

- Of the 115 geologic units studied, 44 had at least one sample with arsenic or uranium concentrations that exceeded the respective constituent's EPA MCL.

\section{Introduction}

Arsenic and uranium occurrence in groundwater used for drinking has been a concern owing to the potential health risks that can occur when concentrations of these constituents in drinking water meet or exceed established human health standards. Previous studies in New England (Ayotte and others, 2003, 2006; Montgomery and others, 2003; Colman, 2011; Flanagan and others, 2014) have shown a strong association between geologic setting and arsenic and uranium concentrations in groundwater. A previous study (Flanagan and Brown, 2017) examined arsenic and uranium concentrations in water samples collected from 674 wells completed in 81 of the 156 geologic units in Connecticut and found that 7 percent of samples collected from 19 geologic units contained either arsenic or uranium concentrations exceeding the U.S. Environmental Protection Agency's (EPA) maximum contaminant levels (MCLs) for drinking-water supplies of 10 micrograms per liter $(\mu \mathrm{g} / \mathrm{L})$ for arsenic or $30 \mu \mathrm{g} / \mathrm{L}$ for uranium. This study, completed by the U.S. Geological Survey (USGS) in cooperation with the Connecticut Department of Public Health (DPH) during 2013-18, expands on the 2017 study with the inclusion of additional samples and a focus on areas of the State with few or no samples. Additionally, this study provides a statewide spatially weighted assessment and updated bedrock geology occurrence information for arsenic and uranium across the State and supporting datasets (Gross, 2020).

\section{Arsenic and Uranium Concentration Data Sources}

The objective of this study was to analyze new data on arsenic and uranium concentrations of samples collected from private wells throughout areas of Connecticut that have been poorly represented in past studies (Flanagan and Brown, 2017) in order to fill data gaps across the State. Several towns in central Connecticut were omitted from sample collection efforts and the subsequent statewide-scale proportion assessment because these towns were assumed to be serviced primarily by public water supply and would contain no or few actively used domestic wells (fig. 1). Groundwater-quality data that were collected, geo-coded, and compiled by the DPH were used in the assessment. Sample collection methods are described in Flanagan and Brown (2017). In figure 1, well locations were offset by one-fourth mile to maintain the confidentiality of the well owner's identity. 

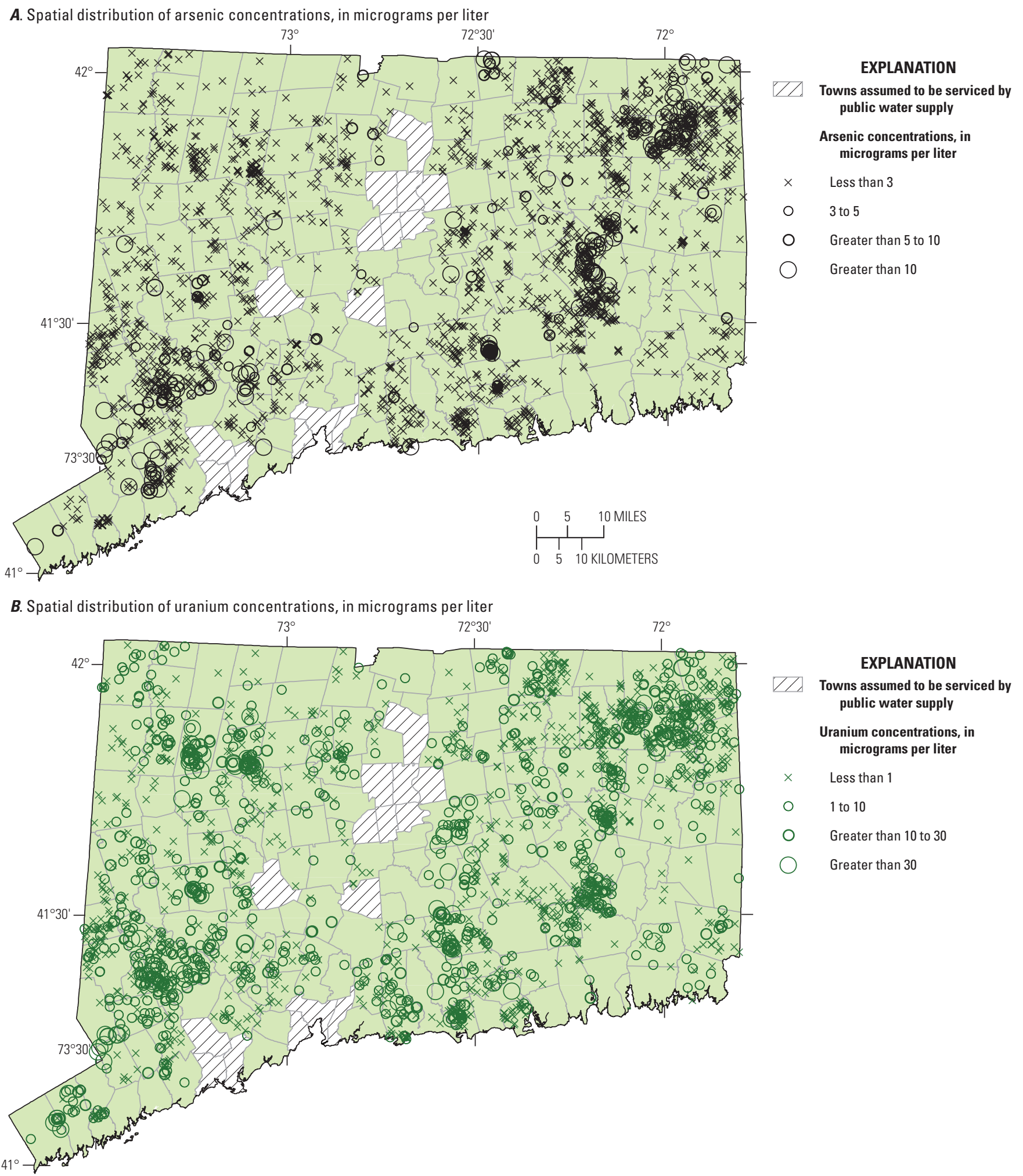

Base from Connecticut Department of Environment Protection, 2005

1:24,000 Lambert Conformal Conic projection: standard parallels $41.20^{\circ} \mathrm{N}$ and $41.87^{\circ} \mathrm{N}$

central meridian $72.75^{\circ} \mathrm{W}$, latitude of origin $40.83^{\circ}$

Figure 1. Concentrations of $A$, arsenic in water samples from 2,433 private wells and $B$, uranium in water samples from 2,191 private wells in Connecticut, 2013-18. Well locations have been offset by one-fourth mile to maintain the confidentiality of the well owner's identity. [<, less than; $>$, greater than; $\mu \mathrm{g} / \mathrm{L}$, micrograms per liter] 
As part of the quality assurance plan for this study, the USGS submitted 11 standard reference samples to the DPH Laboratory with known concentrations of arsenic and uranium spanning the range of expected environmental concentrations. The standard reference samples were supplied by the USGS Branch of Quality Systems in Denver, Colorado, and provided an independent analysis of measurable bias. Results from the analysis of the standard reference samples (table 1) indicated no measurable bias, with all but two relative percent difference values less than 10 percent (Mueller and others, 2015).

\section{Arsenic and Uranium Concentrations in the State}

Arsenic concentrations ranged mostly (95th percentile) from less than 3 to $8.3 \mu \mathrm{g} / \mathrm{L}$ (table 2). Uranium concentrations ranged mostly (95th percentile) from less than 1 to $32 \mu \mathrm{g} / \mathrm{L}$ (table 2). Arsenic concentrations at or greater than the minimum reporting level (MRL) of $3 \mu \mathrm{g} / \mathrm{L}$ were measured in 248 (10.2 percent) of 2,433 samples, whereas uranium concentrations at or greater than the MRL of $1 \mu \mathrm{g} / \mathrm{L}$ were measured in 1,016 (46.4 percent) of 2,191 samples (table 2). Without adjustment by spatial weighting, arsenic concentrations equal to or exceeding the MCL of $10 \mu \mathrm{g} / \mathrm{L}$ were measured in 102 (4.2 percent) samples, and uranium concentrations equal to or exceeding the MCL of $30 \mu \mathrm{g} / \mathrm{L}$ were measured in 118 (5.4 percent) samples (table 2).

\section{Arsenic and Uranium Spatially Weighted Assessment}

Areas across Connecticut have variable amounts of data representing concentrations of arsenic and uranium in water from private bedrock-aquifer wells (fig. 1). In some parts of the State, there are relatively few sample locations, whereas in other areas, sample locations are clustered (fig. 1). In order to delineate the occurrence and distribution of arsenic and uranium in private wells in an unbiased way, a spatially weighted assessment method was used to represent the proportion of affected areas across the State. The spatially weighted assessment describes the proportion of the State, excluding towns assumed to be served primarily by public water supply, that contains concentrations of a constituent (arsenic or uranium) greater than a specified threshold and is nondimensional and spatially unbiased (Belitz and others, 2015). This statistical approach was based on a set of randomized equal-area grid cells (see fig. 2); one grid was created for arsenic, with 130 grid cells, and one was created for uranium, with 110 grid cells (Scott, 1990). Separate grids were created for arsenic and uranium so that the number of grid cells could be maximized and account for the differing amounts of samples available for each constituent. There are 242 more samples and 20 more grid cells for arsenic than uranium (tables 2 and 3). Each grid cell contains between 1 and 86 wells with sample concentrations for the arsenic set of 130 grid cells and between 1 and 102 wells with sample concentrations for the uranium set of

Table 1. Inventory of standard reference samples for arsenic and uranium concentrations, 2015-18.

[SRS, standard reference sample; \#, number; $\mu \mathrm{g} / \mathrm{L}$, micrograms per liter; MPV, most probable value; DPH, Connecticut Department of Public Health Laboratory in Rocky Hill, Connecticut; RPD, relative percent difference; <, less than; NA, not applicable]

\begin{tabular}{|c|c|c|c|c|c|c|c|}
\hline \multirow{2}{*}{ SRS lot \# } & \multirow{2}{*}{$\begin{array}{c}\text { Submission } \\
\text { date }\end{array}$} & \multicolumn{3}{|c|}{ Arsenic concentration, in $\mu \mathrm{g} / \mathrm{L}$} & \multicolumn{3}{|c|}{ Uranium concentration, in $\mu \mathrm{g} / \mathrm{L}$} \\
\hline & & MPV & DPH & RPD' & MPV & DPH & RPD $^{1}$ \\
\hline $\mathrm{T}-219$ & $6 / 30 / 2015$ & 3.51 & $<3.0$ & NA & 1.58 & 1.5 & 5.2 \\
\hline $\mathrm{T}-201$ & $7 / 28 / 2015$ & 24.4 & 23 & 5.9 & 9.22 & 9.2 & 0.2 \\
\hline $\mathrm{T}-201 \mathrm{~b}$ & $8 / 18 / 2015$ & 24.4 & 23 & 5.9 & 9.22 & 9.1 & 1.3 \\
\hline $\mathrm{T}-217$ & $8 / 31 / 2015$ & 5.99 & 5.8 & 3.2 & 1.78 & 1.7 & 4.6 \\
\hline $\mathrm{T}-217 \mathrm{~B}$ & 9/29/2015 & 5.99 & 5.2 & 14.1 & 1.78 & 1.7 & 4.6 \\
\hline $\mathrm{T}-201 \mathrm{c}$ & 9/29/2015 & 24.4 & 22 & 10.3 & 9.22 & 9.3 & 0.9 \\
\hline $\mathrm{T}-221 \mathrm{a}$ & 9/3/2017 & 17.7 & 17 & 4.0 & 1.49 & 1.4 & 6.2 \\
\hline $\mathrm{T}-217 \mathrm{a}$ & $9 / 11 / 2017$ & 5.99 & 5.7 & 5.0 & 1.78 & 1.7 & 4.6 \\
\hline T-193a & $10 / 3 / 2017$ & 3.44 & 3.2 & 7.2 & 1.7 & 1.7 & 0 \\
\hline T-201b & $10 / 24 / 2017$ & 24.4 & 24 & 1.7 & 9.22 & 9.2 & 0.2 \\
\hline $\mathrm{T}-217 \mathrm{~b}$ & $4 / 30 / 2018$ & 5.99 & 5.5 & 8.5 & 1.78 & 1.8 & 1.1 \\
\hline
\end{tabular}

${ }^{1} \mathrm{RPD}=[\mid($ Sample $1-$ Sample 2) $\mid /$ Average (Sample 1 + Sample 2) $] \times 100$, where sample 1 is the MPV value and sample 2 is the DPH value. 

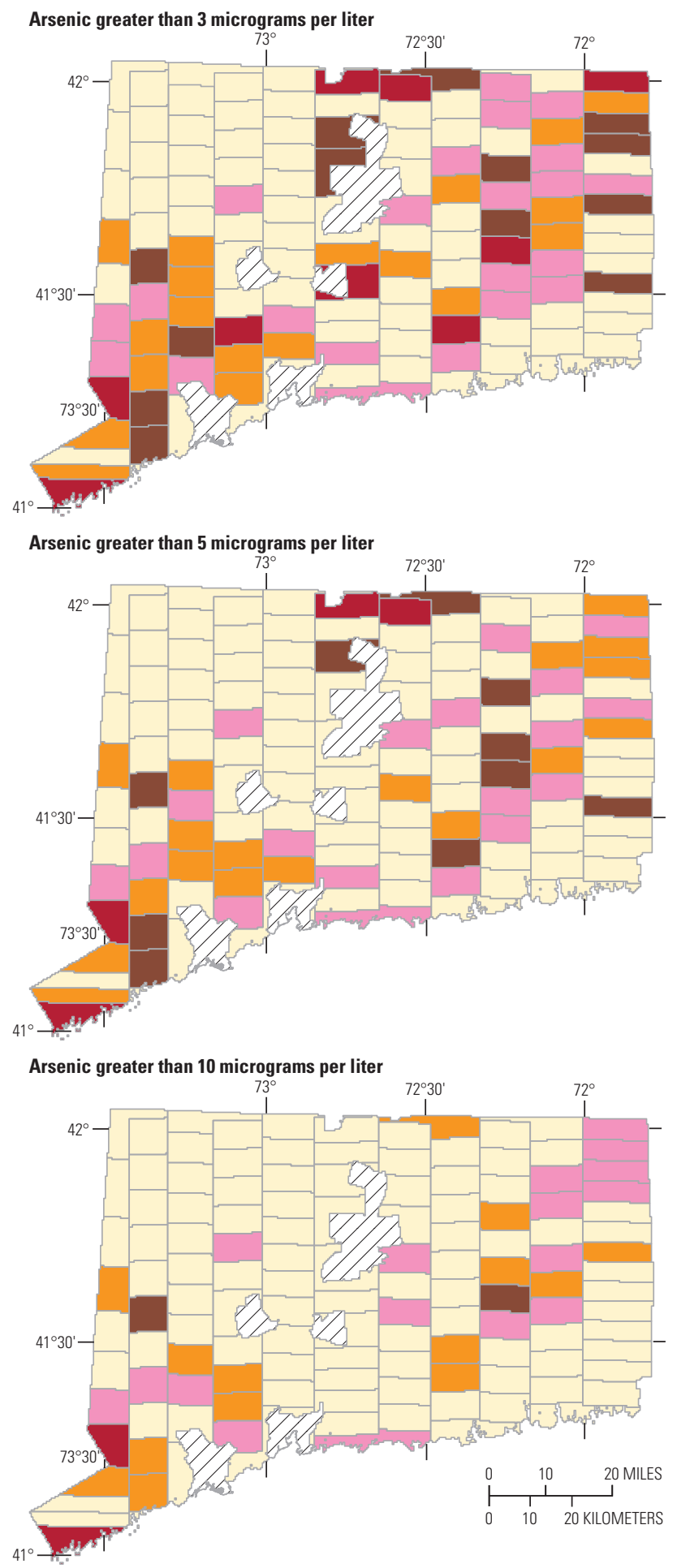

Base from Connecticut Department of Environment Protection, 2005

1:24,000 Lambert Conformal Conic projection: standard parallels $41.20^{\circ} \mathrm{N}$ and $41.87^{\circ} \mathrm{N}$, central meridian $72.75^{\circ} \mathrm{W}$, latitude of origin $40.83^{\circ}$
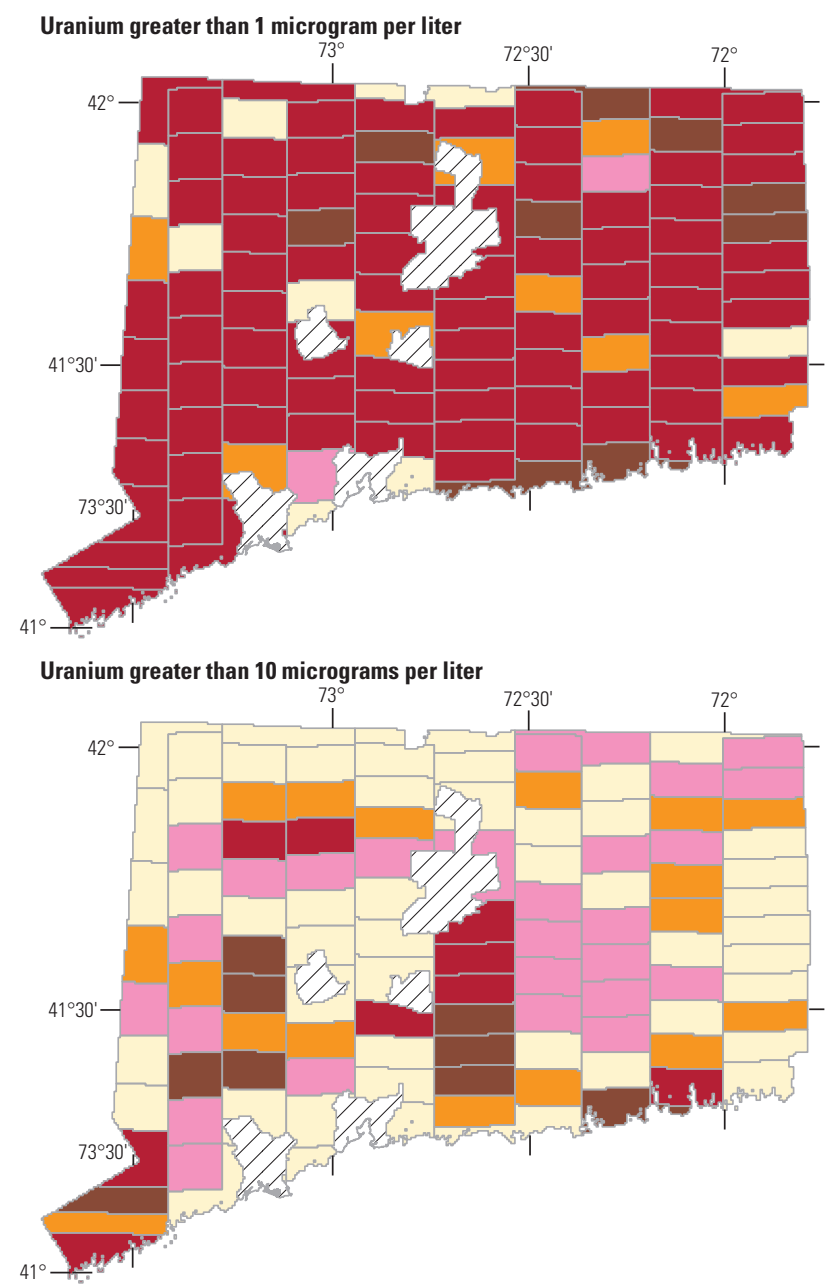

Uranium greater than $30 \underset{73^{\circ}}{\text { micrograms per liter }}$

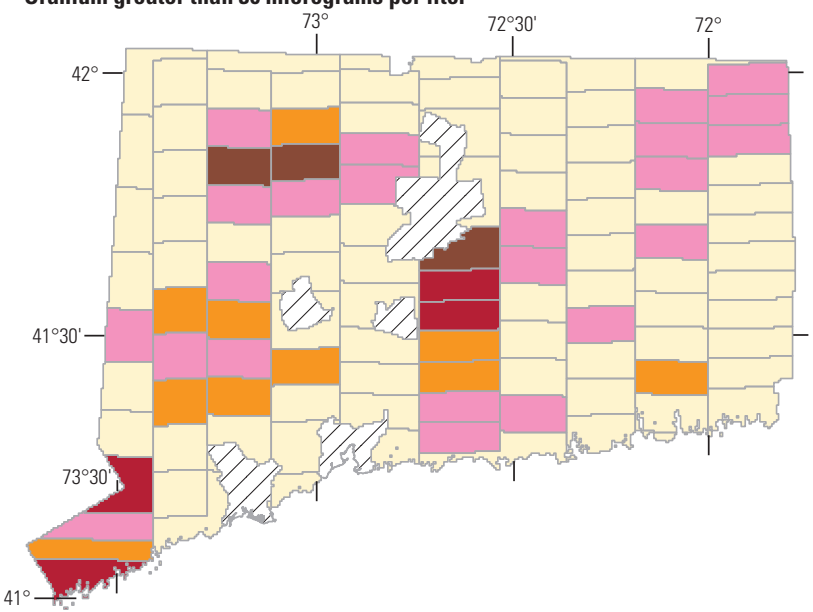

\section{EXPLANATION}

Towns assumed to be serviced by public water supply

Proportion of wells in grid cell with values above noted concentration, in percent Less than 1

1 to 10

Greater than 10 to 20

Greater than 20 to 30

Greater than 30

Figure 2. Spatially weighted statewide-scale proportion of wells within grid cells for arsenic and uranium. 
110 grid cells. For each constituent, spatially weighted, cellwide proportions were determined by computing the proportion of wells with sample concentrations exceeding specific thresholds for each grid cell (Belitz and others, 2010). The specific thresholds include greater than $3 \mu \mathrm{g} / \mathrm{L}$, greater than $5 \mu \mathrm{g} / \mathrm{L}$, and greater than $10 \mu \mathrm{g} / \mathrm{L}$ for arsenic and greater than $1 \mu \mathrm{g} / \mathrm{L}$, greater than $10 \mu \mathrm{g} / \mathrm{L}$, and greater than $30 \mu \mathrm{g} / \mathrm{L}$ for uranium, representing low, moderate, and high value thresholds, respectively, for each constituent (fig. 2). The calculated cell proportions for low, moderate, and high value thresholds for arsenic and uranium were then averaged across the State to determine one spatially weighted statewide-scale proportion value for each of the three thresholds associated with each constituent (table 3; Belitz and others, 2010).

The spatially distributed, randomized equal-area grid approach yields a view of groundwater quality in which all areas are weighted equally, and regions with a high density of groundwater use or with high density of potential arsenic or uranium in groundwater are not preferentially represented (Belitz and others, 2010; Scott, 1990). Arsenic was present at high concentrations (greater than $10 \mu \mathrm{g} / \mathrm{L}$ ) in 3.9 percent of the State of Connecticut, whereas uranium was present at high concentrations (greater than $30 \mu \mathrm{g} / \mathrm{L}$ ) in 4.7 percent of the State (table 3). Figure 2 illustrates that low uranium concentrations (greater than $1 \mu \mathrm{g} / \mathrm{L}$ ) are relatively ubiquitous across the State of Connecticut, with these concentrations present in 44.9 percent of the State (table 3), and account for greater than 30 percent of the proportion of wells in most grid cells (fig. 2). Low arsenic concentrations (greater than $3 \mu \mathrm{g} / \mathrm{L}$ ) were not as common or widespread (fig. 2) as that for uranium concentrations, perhaps in part, owing to the higher reporting level (table 2).

Table 2. Arsenic concentrations in water samples from 2,433 private wells and uranium concentrations in water samples from 2,191 private wells in Connecticut, 2013-18.

[MRL, minimum reporting level; $\geq$, greater than or equal to; $\mu \mathrm{g} / \mathrm{L}$, micrograms per liter; <, less than; >, greater than; Min., Minimum; Max., Maximum; MCL, maximum contaminant level]

\begin{tabular}{|c|c|c|c|c|c|c|c|c|c|c|c|}
\hline \multirow{3}{*}{ Constituent } & \multirow{3}{*}{$\begin{array}{c}\text { Number of } \\
\text { samples }\end{array}$} & \multirow{3}{*}{$\begin{array}{l}\text { MRL, } \\
\text { in } \\
\mu \mathrm{g} / \mathrm{L}\end{array}$} & \multirow{3}{*}{$\begin{array}{l}\text { Number of wells } \\
\text { with concentration } \\
\geq \text { MRL (percent) }\end{array}$} & \multicolumn{6}{|c|}{ Concentration, in $\mu \mathrm{g} / \mathrm{L}$} & \multirow{3}{*}{$\begin{array}{l}\text { MCL, } \\
\text { in } \\
\mu \mathrm{g} / \mathrm{L}\end{array}$} & \multirow{3}{*}{$\begin{array}{l}\text { Number of wells } \\
\text { with concentration } \\
\text { > MCL (percent) }\end{array}$} \\
\hline & & & & \multicolumn{6}{|c|}{ Percentile } & & \\
\hline & & & & Min. & 50 & 75 & 90 & 95 & Max. & & \\
\hline Arsenic & 2,433 & 3 & $248(10.2)$ & $<3.0$ & $<3.0$ & $<3.0$ & 3 & 8.3 & 1,650 & 10 & $102(4.2)$ \\
\hline Uranium & 2,191 & 1 & $1,016(46.4)$ & $<1.0$ & $<1.0$ & 3.6 & 12 & 32 & 3,170 & 30 & $118(5.4)$ \\
\hline
\end{tabular}

Table 3. Spatially weighted statewide-scale proportions for arsenic and uranium during 2013-18 from the Connecticut Department of Public Health database.

$[>$, greater than; $\mu \mathrm{g} / \mathrm{L}$, micrograms per liter $]$

\begin{tabular}{|c|c|c|c|}
\hline \multirow{2}{*}{$\begin{array}{l}\text { Number } \\
\text { of grid } \\
\text { cells }\end{array}$} & \multicolumn{3}{|c|}{ Spatially weighted statewide-scale proportion } \\
\hline & $\begin{array}{l}\text { Low values } \\
\text { (percent) }\end{array}$ & $\begin{array}{l}\text { Moderate values } \\
\text { (percent) }\end{array}$ & $\begin{array}{c}\text { High values } \\
\text { (percent) }\end{array}$ \\
\hline \multicolumn{4}{|c|}{ Arsenic } \\
\hline 130 & $\begin{array}{c}>3 \mu \mathrm{g} / \mathrm{L} \\
(8.7)\end{array}$ & $\begin{array}{c}>5 \mu \mathrm{g} / \mathrm{L} \\
(6.6)\end{array}$ & $\begin{array}{c}>10 \mu \mathrm{g} / \mathrm{L} \\
(3.9)\end{array}$ \\
\hline \multicolumn{4}{|c|}{ Uranium } \\
\hline & $\begin{array}{c}>1 \mu \mathrm{g} / \mathrm{L} \\
(44.9)\end{array}$ & $\begin{array}{c}>10 \mu \mathrm{g} / \mathrm{L} \\
(10.1)\end{array}$ & $\begin{array}{c}>30 \mu \mathrm{g} / \mathrm{L} \\
(4.7)\end{array}$ \\
\hline
\end{tabular}




\section{Arsenic and Uranium Occurrence in Relation to Bedrock Geology}

For this study, it was assumed that each sampled well was drilled and completed in the mapped bedrock geologic unit (referred to as "geologic unit" in this report) represented at the well's location, as identified on the bedrock geological map of Connecticut (Rodgers, 1985; Connecticut Department of Environmental Protection, 2000). Corresponding arsenic and uranium samples were grouped according to the geologic units in which the sampled wells were located (table 4).

Of the 156 geologic units in the State, 115 units (covering 98.1 percent of the land area) were represented by at least one water sample analyzed for arsenic and (or) uranium (table 4). Of the 115 geologic units represented, 21 geologic units had only 1 arsenic sample, 45 geologic units had 2 to 10 arsenic samples, and 49 geologic units had more than 10 arsenic samples. Of the 113 geologic units with uranium samples, 20 geologic units had only 1 uranium sample, 44 geologic units had 2 to 10 uranium samples, and 49 geologic units had more than 10 uranium samples. The 115 geologic units with samples were organized under 11 different major categories of bedrock, which are listed in table 4 and can be viewed in figure 1 of Flanagan and Brown (2017). These major categories of bedrock are based on groups of individual geologic units with similar geochemical and lithological properties (Robinson and Kapo, 2003). The percentage of arsenic and uranium samples from each geologic unit containing concentrations exceeding MCLs was computed, and geologic units were grouped and shaded on the basis of percentage ranges (fig. 3). MCL exceedance percentages computed for geologic units for this study provide new and updated information on arsenic and uranium concentrations in Connecticut groundwater; however, they may not represent the actual hazard for existing and future wells in geologic units. Some of the local geologic maps for New England have been revised since the publication of the Rodgers (1985) geological map compilation and the Robinson and Kapo (2003) lithogeochemical map (M.A. Thomas, Connecticut Geological Survey, written commun., 2019), but these revisions are not reflected in the geological map versions used in this study. In figure 3, well locations are offset by one-fourth mile to maintain the confidentiality of the well owner's identity.

The results show that geologic units had widely differing rates of arsenic and uranium concentrations exceeding MCLs (table 4). Twenty-two of 115 geologic units had at least one sample with arsenic concentrations that exceeded the MCL of $10 \mu \mathrm{g} / \mathrm{L}$, and 32 of 113 geologic units had at least one sample with uranium concentrations that exceeded the MCL of $30 \mu \mathrm{g} / \mathrm{L}$. The pelitic rocks category had 7 (out of 28) geologic units with at least one arsenic concentration that exceeded the MCL of $10 \mu \mathrm{g} / \mathrm{L}$ and 8 geologic units with at least one uranium concentration that exceeded the MCL of $30 \mu \mathrm{g} / \mathrm{L}$. The mafic rocks category contained 10 (out of 25) geologic units with at least one uranium concentration that exceeded the MCL. 
Table 4. Arsenic and uranium concentrations that exceed U.S. Environmental Protection Agency's maximum contaminant levels in samples from private wells in Connecticut, by geologic unit and major bedrock category, 2013-18.

[Geologic unit names are the Connecticut Department of Environmental Protection preferred names as modified from Rodgers (1985). Major categories of bedrock (subheadings) are modified from Robinson and Kapo (2003). Color shadings indicate the percentage of wells with exceedances greater than concentration thresholds in ranges of: $\square$, no data; , less than $(<) 1$ percent; $\square, 1$ to 10 percent; $\square$, greater than $(>) 10$ to 20 percent; $\square$, greater than (>) 20 to 30 percent; and $\boldsymbol{\square}$, greater than $(>) 30$ percent. MCL, U.S. Environmental Protection Agency maximum contaminant level enforceable for public water supplies; $\mu \mathrm{g} / \mathrm{L}$, micrograms per liter; NA, not available; -, no uranium samples from geologic unit]

\begin{tabular}{|c|c|c|c|c|c|c|}
\hline \multirow[t]{2}{*}{ Geologic unit name' ${ }^{1}$} & \multirow{2}{*}{$\begin{array}{l}\text { Geologic } \\
\text { unit code }^{1}\end{array}$} & \multicolumn{2}{|c|}{ Number of samples } & \multicolumn{2}{|c|}{$\begin{array}{l}\text { Percentage of water } \\
\text { samples with concentrations } \\
\text { exceeding MCL, in } \mu \mathrm{g} / \mathrm{L}\end{array}$} & \multirow{2}{*}{$\begin{array}{l}\text { Percentage } \\
\text { of study area } \\
\text { underlain by } \\
\text { geologic unit }\end{array}$} \\
\hline & & Arsenic & Uranium & $\begin{array}{l}\text { Arsenic } \\
>10 \mu \mathrm{g} / \mathrm{L}\end{array}$ & $\begin{array}{l}\text { Uranium } \\
>30 \mu \mathrm{g} / \mathrm{L}\end{array}$ & \\
\hline \multicolumn{7}{|c|}{ Avalon Granites } \\
\hline "Scituate" Granite Gneiss & Zss & 16 & 16 & 0 & 0 & 0.7 \\
\hline Mamacoke Formation & Zwm & 6 & 6 & 0 & 16.7 & 0.8 \\
\hline Plainfield Formation & $\mathrm{Zp}$ & 25 & 24 & 0 & 0 & 1.6 \\
\hline $\begin{array}{l}\text { Plainfield Formation, Stony Creek Granite Gneiss and } \\
\text { Narragansett Pier Granite undivided }\end{array}$ & $\mathrm{Zp}+\mathrm{Zsc}+\mathrm{Pn}$ & 10 & 11 & 10 & 0 & $<0.2$ \\
\hline Ponaganset Gneiss & Zsp & 3 & 3 & 0 & 0 & 0.3 \\
\hline $\begin{array}{l}\text { Potter Hill Granite Gneiss and Narragansett Pier Granite } \\
\text { undivided }\end{array}$ & $\mathrm{Zsph}+\mathrm{Pn}$ & 1 & 1 & 0 & 0 & $<0.2$ \\
\hline Rope Ferry Gneiss & Zwr & 18 & 18 & 0 & 0 & 1.2 \\
\hline $\begin{array}{l}\text { Stony Creek Granite Gneiss and Narragansett Pier } \\
\text { Granite undivided }\end{array}$ & $\mathrm{Zsc}+\mathrm{Pn}$ & 3 & 2 & 0 & 0 & $<0.2$ \\
\hline \multicolumn{7}{|c|}{ Basalt } \\
\hline Buttress Dolerite & $\mathrm{Jb}$ & 1 & 1 & 0 & 0 & 0.2 \\
\hline Hampden Basalt & Jha & 3 & 3 & 0 & 33.3 & 0.3 \\
\hline Holyoke Basalt & Jho & 5 & 5 & 0 & 0 & 1.2 \\
\hline \multicolumn{7}{|c|}{ Calcgranofels } \\
\hline Lower Member of Bigelow Brook Formation & SObl & 25 & 25 & 0 & 0 & 0.7 \\
\hline Southbridge Formation & SOs? & 6 & 6 & 0 & 0 & 0.3 \\
\hline Southbridge Formation & SOs & 60 & 58 & 0 & 0 & 0.8 \\
\hline \multicolumn{7}{|c|}{ Carbonate-Bearing Metasedimentary Rocks } \\
\hline Basal Marble Member of Walloomsac Schist & Owm & 11 & 11 & 9.1 & 0 & 0.6 \\
\hline Stockbridge Marble & OCs & 14 & 13 & 7.1 & 0 & 0.9 \\
\hline Unit a of Stockbridge Marble & Csa & 1 & 1 & 0 & 0 & $<0.2$ \\
\hline Unit b of Stockbridge Marble & $\mathrm{Csb}$ & 9 & 9 & 0 & 0 & 0.4 \\
\hline Unit c of Stockbridge Marble & $\mathrm{Csc}$ & 9 & 9 & 0 & 0 & 0.6 \\
\hline Units e and d of Stockbridge Marble & Ose & 2 & 2 & 0 & 0 & $<0.2$ \\
\hline
\end{tabular}


Table 4. Arsenic and uranium concentrations that exceed U.S. Environmental Protection Agency's maximum contaminant levels in samples from private wells in Connecticut, by geologic unit and major bedrock category, 2013-18. - Continued

[Geologic unit names are the Connecticut Department of Environmental Protection preferred names as modified from Rodgers (1985). Major categories of bedrock (subheadings) are modified from Robinson and Kapo (2003). Color shadings indicate the percentage of wells with exceedances greater than concentration thresholds in ranges of: $\square$, no data; , less than $(<) 1$ percent; $\square, 1$ to 10 percent; $\square$, greater than (>) 10 to 20 percent; $\square$, greater than $(>) 20$ to 30 percent; and $\square$, greater than (>) 30 percent. MCL, U.S. Environmental Protection Agency maximum contaminant level enforceable for public water supplies; $\mu \mathrm{g} / \mathrm{L}$, micrograms per liter; NA, not available; -, no uranium samples from geologic unit]

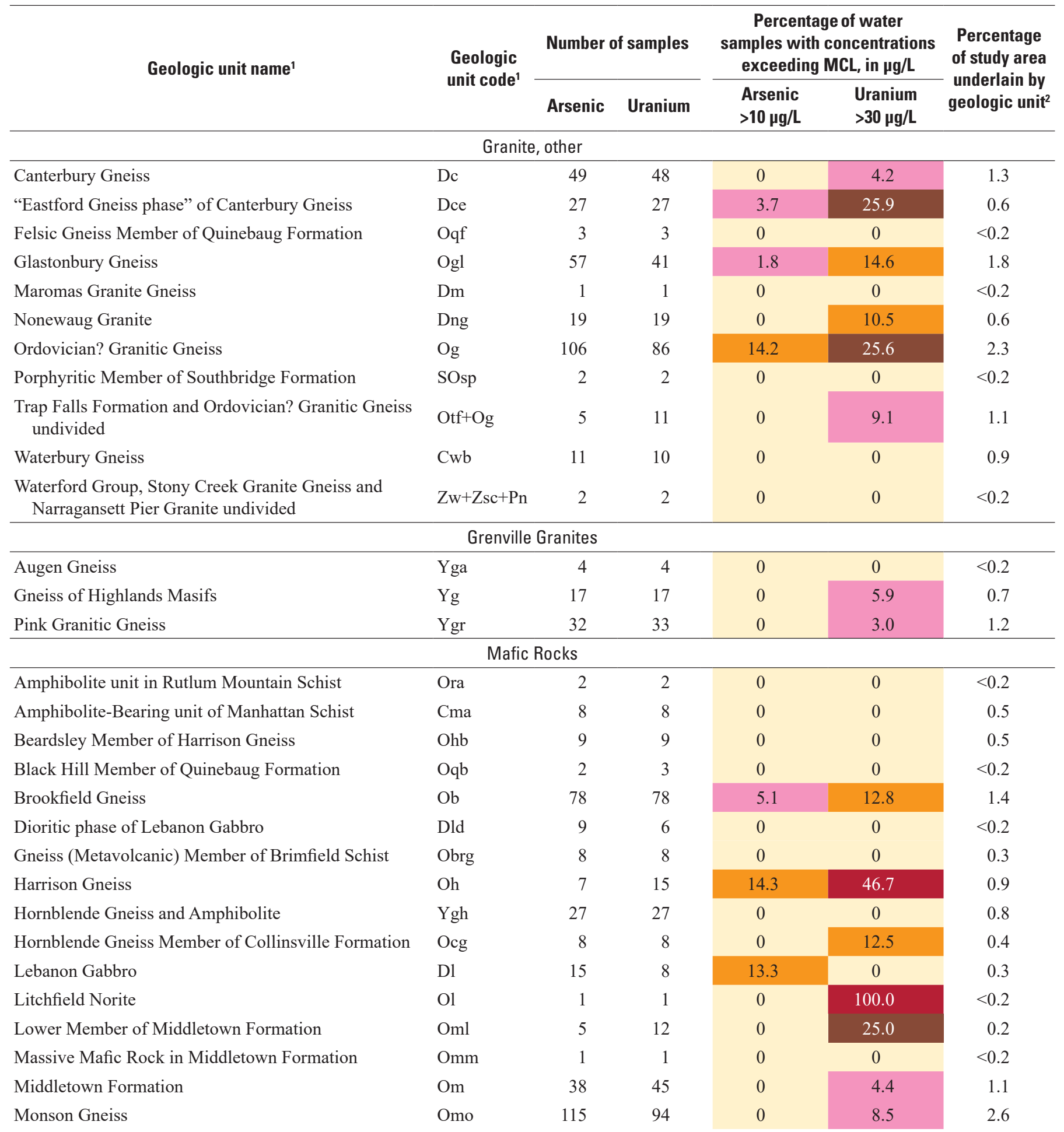


Table 4. Arsenic and uranium concentrations that exceed U.S. Environmental Protection Agency's maximum contaminant levels in samples from private wells in Connecticut, by geologic unit and major bedrock category, 2013-18. - Continued

[Geologic unit names are the Connecticut Department of Environmental Protection preferred names as modified from Rodgers (1985). Major categories of bedrock (subheadings) are modified from Robinson and Kapo (2003). Color shadings indicate the percentage of wells with exceedances greater than concentration thresholds in ranges of: $\square$, no data; , less than $(<) 1$ percent; $\square, 1$ to 10 percent; $\square$, greater than $(>) 10$ to 20 percent; $\square$, greater than $(>) 20$ to 30 percent; and $\boldsymbol{\square}$, greater than $(>) 30$ percent. MCL, U.S. Environmental Protection Agency maximum contaminant level enforceable for public water supplies; $\mu \mathrm{g} / \mathrm{L}$, micrograms per liter; NA, not available; -, no uranium samples from geologic unit]

\begin{tabular}{|c|c|c|c|c|c|c|}
\hline \multirow{2}{*}{ Geologic unit name' } & \multirow{2}{*}{$\begin{array}{l}\text { Geologic } \\
\text { unit code }^{1}\end{array}$} & \multicolumn{2}{|c|}{ Number of samples } & \multicolumn{2}{|c|}{$\begin{array}{c}\text { Percentage of water } \\
\text { samples with concentrations } \\
\text { exceeding MCL, in } \mu \mathrm{g} / \mathrm{L}\end{array}$} & \multirow{2}{*}{$\begin{array}{l}\text { Percentage } \\
\text { of study area } \\
\text { underlain by } \\
\text { geologic unit }{ }^{2}\end{array}$} \\
\hline & & Arsenic & Uranium & $\begin{array}{l}\text { Arsenic } \\
>10 \mu \mathrm{g} / \mathrm{L}\end{array}$ & $\begin{array}{l}\text { Uranium } \\
>30 \mu g / L\end{array}$ & \\
\hline \multicolumn{7}{|c|}{ Mafic Rocks-Continued } \\
\hline Mylonite along Paleozoic Faults & Pzmy & 3 & 3 & 0 & 0 & $<0.2$ \\
\hline Pumpkin Ground Member of Harrison Gneiss & Ohp & 4 & 4 & 0 & 0 & 0.5 \\
\hline Quinebaug Formation & $\mathrm{Oq}$ & 89 & 76 & 1.1 & 0 & 2.0 \\
\hline Rowe Schist & OCr? & 2 & 2 & 0 & 0 & $<0.2$ \\
\hline Rowe Schist & $\mathrm{OCr}$ & 54 & 55 & 1.9 & 1.8 & 1.9 \\
\hline \multicolumn{7}{|c|}{ Mesozoic Basin Sediments } \\
\hline East Berlin Formation & Jeb & 14 & 14 & 0 & 0 & 1.3 \\
\hline New Haven Arkose & TRnh & 61 & 59 & 0 & 1.7 & 6.3 \\
\hline Portland Arkose & $\mathrm{Jp}$ & 57 & 45 & 8.8 & 0 & 8.0 \\
\hline Shuttle Meadow Formation & Jsm & 14 & 13 & 0 & 0 & 0.5 \\
\hline \multicolumn{7}{|c|}{ Metamorphic Rocks, other } \\
\hline Bristol Gneiss & Obs & 3 & 3 & 0 & 0 & 0.4 \\
\hline Clough Quartzite & Sbc & 1 & 1 & 0 & 0 & $<0.2$ \\
\hline $\begin{array}{l}\text { Basal Member of Taine Mountain Formation } \\
\text { around Waterbury Dome }\end{array}$ & Otb & 3 & 3 & 0 & 0 & 0.4 \\
\hline Cobble Mountain Formation & Ocm & 1 & 1 & 0 & 0 & 0.4 \\
\hline Collinsville Formation & Oc & 33 & 32 & 12.1 & 3.1 & 1.1 \\
\hline Everett Schist & $\mathrm{Ce}$ & 1 & 1 & 0 & 0 & 0.2 \\
\hline Golden Hill Schist & Ogh & 3 & 3 & 0 & 0 & 0.3 \\
\hline Hoosac Schist & $\mathrm{Ch}$ & 40 & 40 & 0 & 20.0 & 1.1 \\
\hline Littleton Formation & Dbl & 7 & 7 & 0 & 0 & 0.4 \\
\hline Manhattan Schist & $\mathrm{Cm}$ & 37 & 37 & 0 & 8.1 & 2.0 \\
\hline Mount Pisgah Member of Littleton Formation & Dblm & 4 & 3 & 0 & 0 & $<0.2$ \\
\hline Oronoque Schist & Oo & 1 & 1 & 0 & 0 & 0.5 \\
\hline
\end{tabular}


Table 4. Arsenic and uranium concentrations that exceed U.S. Environmental Protection Agency's maximum contaminant levels in samples from private wells in Connecticut, by geologic unit and major bedrock category, 2013-18._-Continued

[Geologic unit names are the Connecticut Department of Environmental Protection preferred names as modified from Rodgers (1985). Major categories of bedrock (subheadings) are modified from Robinson and Kapo (2003). Color shadings indicate the percentage of wells with exceedances greater than concentration thresholds in ranges of: $\square$, no data; , less than $(<) 1$ percent; $\square, 1$ to 10 percent; $\square$, greater than $(>) 10$ to 20 percent; $\square$, greater than $(>) 20$ to 30 percent; and $\square$, greater than (>) 30 percent. MCL, U.S. Environmental Protection Agency maximum contaminant level enforceable for public water supplies; $\mu \mathrm{g} / \mathrm{L}$, micrograms per liter; NA, not available; -, no uranium samples from geologic unit]

\begin{tabular}{|c|c|c|c|c|c|c|}
\hline \multirow[t]{2}{*}{ Geologic unit name ${ }^{1}$} & \multirow{2}{*}{$\begin{array}{l}\text { Geologic } \\
\text { unit code }\end{array}$} & \multicolumn{2}{|c|}{ Number of samples } & \multicolumn{2}{|c|}{$\begin{array}{c}\text { Percentage of water } \\
\text { samples with concentrations } \\
\text { exceeding } M C L \text {, in } \mu \mathrm{g} / \mathrm{L}\end{array}$} & \multirow{2}{*}{$\begin{array}{l}\text { Percentage } \\
\text { of study area } \\
\text { underlain by } \\
\text { geologic unit }\end{array}$} \\
\hline & & Arsenic & Uranium & $\begin{array}{l}\text { Arsenic } \\
>10 \mu \mathrm{g} / \mathrm{L}\end{array}$ & $\begin{array}{l}\text { Uranium } \\
>30 \mu \mathrm{g} / \mathrm{L}\end{array}$ & \\
\hline \multicolumn{7}{|c|}{ Pelitic Rocks - Continued } \\
\hline Ratlum Mountain Schist & Or? & 12 & 6 & 8.3 & 0 & 0.3 \\
\hline $\begin{array}{l}\text { Ratlum Mountain Schist and Amphibolite unit } \\
\text { in Rutlum Mountain Schist undivided }\end{array}$ & Or+Ora & 1 & 1 & 0 & 0 & $<0.2$ \\
\hline Schist and Granulite Member of Trap Falls Formation & Otfg & 16 & 13 & 0 & 0 & 0.5 \\
\hline Scotland Schist & DSs & 96 & 87 & 16.7 & 1.1 & 1.0 \\
\hline $\begin{array}{l}\text { Scranton Mountain Member of Taine Mountain } \\
\text { Formation }\end{array}$ & Ots & 1 & 1 & 0 & 0 & $<0.2$ \\
\hline Taine Mountain and Collinsville Formation undivided & $\mathrm{Ot}+\mathrm{Oc}$ & 6 & 6 & 16.7 & 33.3 & 0.3 \\
\hline Taine Mountain Formation & Ot & 20 & 20 & 5.0 & 0 & 0.9 \\
\hline Tatnic Hill Formation & Ota & 80 & 68 & 0 & 1.5 & 3.1 \\
\hline The Straits Schist & DSt & 24 & 24 & 12.5 & 0 & 2.1 \\
\hline Trap Falls Formation & Otf & 3 & - & 0 & - & 0.3 \\
\hline Upper Member of Middletown Formation & $\mathrm{Omu}$ & 20 & 9 & 0 & 11.1 & 0.2 \\
\hline Walloomsac Schist & Ow & 11 & 11 & 0 & 0 & 0.5 \\
\hline Wepawaug Schist & DSw & 10 & 8 & 10.0 & 0 & 0.8 \\
\hline Whigville Member of Taine Mountain Formation & Otwv & 1 & 1 & 0 & 0 & $<0.2$ \\
\hline \multicolumn{7}{|c|}{ Sulfidic Schists } \\
\hline Carringtons Pond Member of Trap Falls Formation & Otfc & 3 & 3 & 33.3 & 0 & 0.5 \\
\hline Collins Hill Formation & Och & 23 & 22 & 0 & 4.5 & 0.8 \\
\hline lower slice of Canaan Mountain Schist & $\mathrm{Cmcl}$ & 1 & - & 0 & - & $<0.2$ \\
\hline Rusty Mica Schist and Gneiss & Ygs & 8 & 8 & 0 & 0 & 1.0 \\
\hline Upper Member of Bigelow Brook Formation & SObu & 9 & 9 & 0 & 0 & 0.3 \\
\hline upper slice of Canaan Mountain Schist & $\mathrm{Cmcu}$ & 1 & 1 & 0 & 0 & 0.4 \\
\hline Unmapped Areas & 1 & 1 & 1 & 0 & 0 & 1.1 \\
\hline Overall for the Study Area & NA & 2,433 & 2,191 & 4.4 & 5.4 & 98.1 \\
\hline
\end{tabular}

${ }^{1}$ Geologic units from Connecticut Department of Environmental Protection, 2000; names may not conform to usage by the U.S. Geological Survey. Queries indicate uncertainty about geologic unit identification.

${ }^{2}$ About 1.9 percent of the study area (State of Connecticut) was underlain by 41 individual geologic units from which no water samples were collected. 
A. Percentage of wells, by grouped geologic units with arsenic concentrations greater than 10 micrograms per liter (MCL)

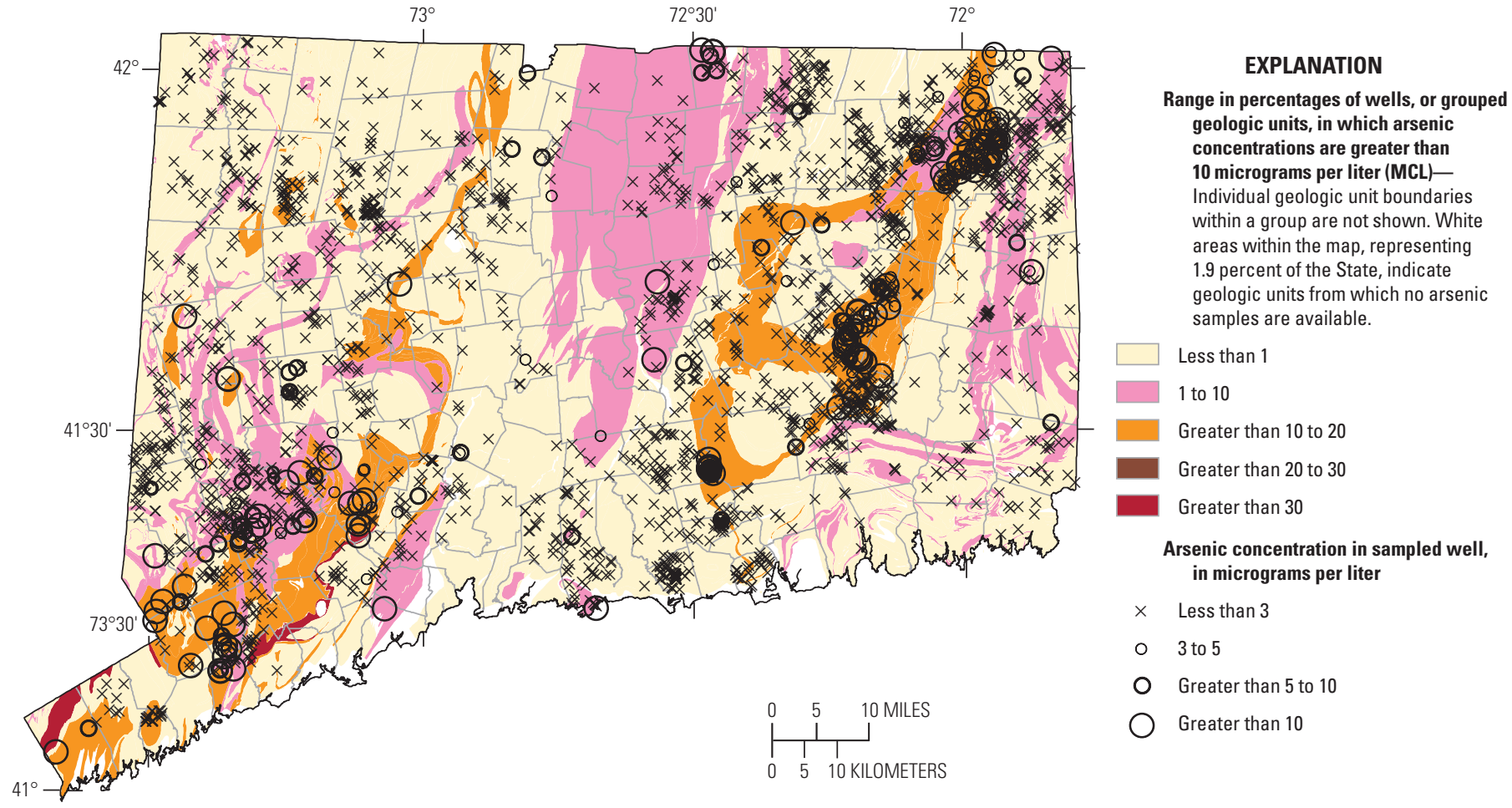

B. Percentage of wells, by grouped geologic units with uranium concentrations greater than 30 micrograms per liter (MCL)

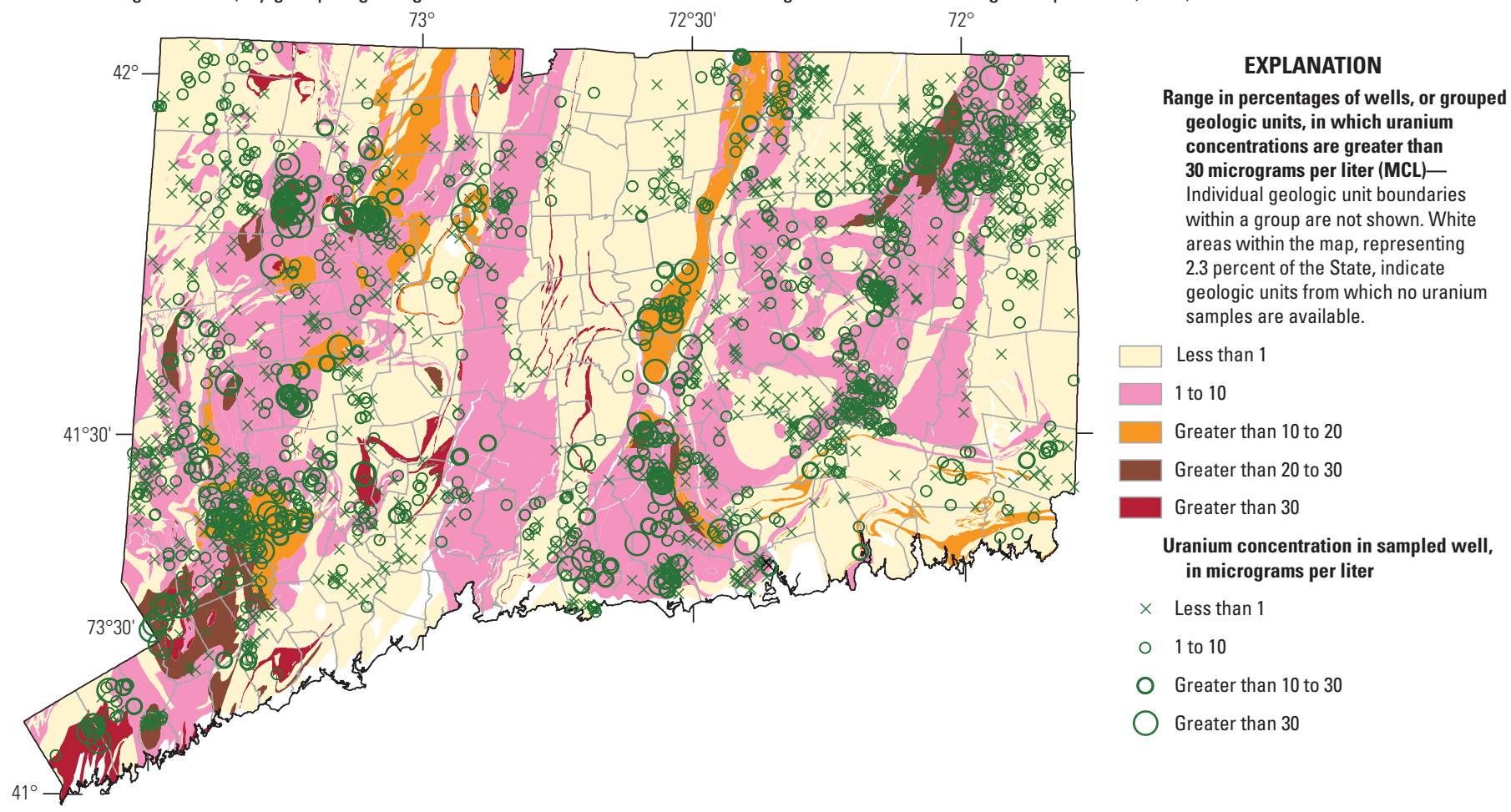

Base from Connecticut Department of Environment Protection, 2005

1:24,000 Lambert Conformal Conic projection: standard parallels $41.20^{\circ} \mathrm{N}$ and $41.87^{\circ} \mathrm{N}$

central meridian $72.75^{\circ} \mathrm{W}$, latitude of origin $40.83^{\circ}$

Figure 3. Spatial distribution and range of percentages of private wells in Connecticut, grouped by geologic units, in which $A$, arsenic concentrations exceeded the maximum concentration level (MCL) of 10 micrograms per liter ( $\mu \mathrm{g} / \mathrm{L})$, and $B$, uranium concentrations exceeded the MCL of $30 \mu \mathrm{g} / \mathrm{L}$. Well locations have been offset by one-fourth mile to maintain the confidentiality of the well owner's identity. Geologic units are listed in table 4. See Rodgers (1985) for the location and description of individual geologic units. 
The Carringtons Pond Member of Trap Falls Formation was the only geologic unit with greater than 30 percent occurrence of arsenic concentrations ( 1 out of 3 samples) exceeding the MCL of $10 \mu \mathrm{g} / \mathrm{L}$ (table 4). Five geologic units (Hampden Basalt, Harrison Gneiss, Litchfield Norite, Sweetheart Mountain Member of Collinsville Formation, and Taine Mountain and Collinsville Formation undivided) had greater than 30 percent of uranium concentrations ( 1 of 3,7 of 15 , 1 of 1,1 of 2 , and 2 of 6 samples, respectively) exceeding the MCL of $30 \mu \mathrm{g} / \mathrm{L}$.

The well containing the highest measured arsenic concentration $(1,650 \mu \mathrm{g} / \mathrm{L})$ in this study is completed in the Basal marble member of Walloomsac Schist geologic unit of the carbonate-bearing metasedimentary rocks bedrock category. Of the 11 samples in this geologic unit, this was the only well containing an arsenic concentration exceeding the MCL of $10 \mu \mathrm{g} / \mathrm{L}$. Eleven geologic units (table 4 ) in the State had a higher percentage (greater than 9.1 percent) of samples with arsenic exceeding $10 \mu \mathrm{g} / \mathrm{L}$ than the Basal marble member of Walloomsac Schist geologic unit. The well with the highest uranium concentration $(3,170 \mu \mathrm{g} / \mathrm{L})$ is completed in the Harrison Gneiss geologic unit of the mafic rocks bedrock category.
This geologic unit had 15 samples, and 46.7 percent of the samples had uranium concentrations exceeding the MCL of $30 \mu \mathrm{g} / \mathrm{L}$. Two other geologic units (table 4) in the State had a higher percentage (greater than 46.7 percent) of samples with uranium exceeding the MCL. These findings demonstrate that wells with arsenic or uranium concentrations exceeding their respective MCLs were not always in the same geologic unit.

The findings of this study also indicate that, for a household in Connecticut relying on a private well for drinking water, the likelihood of the water containing an arsenic or uranium concentration exceeding the constituent's MCL is related to the particular geologic unit in which the household's well is completed. Other factors that can affect arsenic or uranium concentrations are geochemical conditions or residence time for water-rock reactions in the local groundwater flow system. Testing well water is the only way to know whether a contaminant is present. For more information about well testing and treatment guidelines in Connecticut, readers should contact the Connecticut Department of Public Health Private Well Program using the information provided at http://www.ct.gov/ $\mathrm{dph} /$ privatewells. 


\section{References Cited}

Ayotte, J.D., Montgomery, D.L., Flanagan, S.M., and Robinson, K.W., 2003, Arsenic in groundwater in eastern New England: occurrence, controls, and human health implications: Environmental Science and Technology, v. 37, no. 10, p. 2075-2083, accessed February 19, 2019, at https:// nh.water.usgs.gov/Publications/2003/es026211g.pdf.

Ayotte, J.D., Nolan, B.T., Nuckols, J.R., Cantor, K.P., Robinson, G.R., Jr., Baris, Dalsu, Hayes, Laura, Karagas, Margaret, Bress, William, Silverman, D.T., and Lubin, J.H., 2006, Modeling the probability of arsenic in groundwater in New England as a tool for exposure assessment: Environmental Science and Technology, v. 40, p. 3578-3585.

Belitz, K., Fram, M.S., and Johnson, T.D., 2015, Metrics for assessing the quality of groundwater used for public supply, CA, USA: Equivalent-population and area: Environmental Science and Technology, v. 49, 8 p., accessed February 19, 2019, at https://pubs.acs.org/doi/pdf/10.1021/acs. est.5b00265.

Belitz, K., Jurgens, B., Landon, M.K., Fram, M.S., and Johnson, T., 2010, Estimation of aquifer-scale proportion using equal-area grids-Assessment of regional-scale groundwater quality: Water Resources Research, v. 46, W11550, 14 p., accessed February 19, 2019, at https://doi. org/10.1029/2010WR009321.

Colman, J.A., 2011, Arsenic and uranium in water from private wells completed in bedrock of east-central Massachusetts - Concentrations, correlations with bedrock units, and estimated probability maps: U.S. Geological Survey Scientific Investigations Report 2011-5013, 113 p.

Connecticut Department of Environmental Protection, 2000, Bedrock geology - Connecticut: State of Connecticut, Department of Environmental Protection, vector digital data, accessed March 25, 2019, at http://magic.lib.uconn.edu/magic_2/vector/37800/ bedrockpolyct_37800_0000_2000_s50_ctgnhs_1_shp.zip.

Connecticut Department of Environmental Protection, 2005, Connecticut town polygon: State of Connecticut, Department of Environmental Protection, vector digital data, accessed May 22, 2019, at https://www.ct.gov/deep/cwp/ view.asp? $\mathrm{a}=2698 \& q=322898 \&$ deepNav_GID $=1707$.

Flanagan, S.M., and Brown, C.J., 2017, Arsenic and uranium in private wells in Connecticut, 2013-15: U.S. Geological Survey Open-File Report 2017-1046; 8 p. [Also available at https://doi.org/10.3133/ofr20171046].
Flanagan, S.M, Belaval, Marcel, and Ayotte, J.D., 2014, Arsenic, iron, lead, manganese, and uranium concentrations in private bedrock wells in southeastern New Hampshire, 2012-2013: U.S. Geological Survey Fact Sheet 2014-3042, 6 p., appendixes. [Also available at https://doi.org/10.3133/ fs20143042].

Gross, E.L, 2020, Data in support of "Arsenic and Uranium Occurrence in Private Wells in Connecticut, 2013-18, a Spatially-Weighted and Bedrock Geology Assessment": U.S. Geological Survey data release. [Also available at https://doi.org/10.5066/P9KOU55K].

Montgomery, D.L., Ayotte, J.D., Carroll, P.R., and Hamlin, Patricia, 2003, Arsenic concentrations in private bedrock wells in southeastern New Hampshire: U.S. Geological Survey Fact Sheet 03-051, 6 p. [Also available at https://pubs. er.usgs.gov/publication/fs05103].

Mueller, D.K., Schertz, T.L., Martin, J.D., and Sandstrom, M.W., 2015, Design, analysis, and interpretation of field quality-control data for water-sampling projects: U.S. Geological Survey Techniques and Methods, book 4, chap. C4, 54 p. [Also available at http://dx.doi.org/10.3133/tm4C4].

Rodgers, John, comp., 1985, Bedrock geological map of Connecticut: Connecticut Geological and Natural History Survey, Natural Resource Atlas Map Series, scale 1:125,000, 2 sheets, accessed December 12, 2016, at https://ngmdb. usgs.gov/Prodesc/proddesc_54245.htm.

Robinson, G.R., Jr., and Kapo, K.E., 2003, Generalized lithology and lithogeochemical character of near-surface bedrock in the New England region: U.S. Geological Survey OpenFile Report 03-225, 60 p. [Also available at https://pubs. er.usgs.gov/publication/ofr03225.]

Scott, J.C., 1990, Computerized stratified random site-selection approaches for design of a ground-water-quality sampling network: U.S. Geological Survey Water-Resources Investigations Report 90-4101, 109 p. [Also available at https://pubs.er.usgs.gov/publication/wri904101]. 

For additional information, contact::

Director, Pennsylvania Water Science Center

U.S. Geological Survey

215 Limekiln Road

New Cumberland, PA 17070

or visit our website at: https://www.usgs.gov/centers/pa-water

Publishing support provided by the

West Trenton Publishing Service Center 
2. 